BANCODEESPAÑA

Eurosistema

\title{
The increase in TARGET balances in the euro area since 2015
}

Pana Alves, Antonio Millaruelo and Ana del Río 
Abstract

The TARGET2 platform, which is owned by the Eurosystem, processes payments in euro with reserves, i.e. central bank money. The cross-border payment transactions channelled through this platform give rise to central bank claims and liabilities which, when aggregated and netted, produce the so-called TARGET balances. Since 2015, when various extraordinary monetary stimulus measures were introduced by the ECB, there has been a marked increase in aggregate TARGET balances, to levels above those reached during the sovereign debt crisis which took place in the first few years of the current decade. Unlike then, the recent developments do not reflect financial stress or general funding problems in euro area economies, as during the sovereign debt crisis, but are instead mainly linked to the execution of the Eurosystem's asset purchase programme (APP).

Keywords: payment system, TARGET balances, TARGET2, bank reserves, asset purchases, APP.

JEL codes: E42, E50. 
The authors of this article are Pana Alves, Antonio Millaruelo and Ana del Río of the Directorate General Economics, Statistics and Research.

Introduction

TARGET2 and the intrasystem balances
TARGET2 is a pan-European platform for euro payments, owned by the Eurosystem. Its main characteristics are gross settlement, in real time, and it operates with reserves issued by the central bank. ${ }^{1}$ It dates back to the creation of the monetary union owing to the need to guarantee the circulation of liquidity within the euro area securely, rapidly and at a low cost, an essential element for the integration of financial markets and the conduct of a single monetary policy. ${ }^{2}$ Although TARGET2 is a single platform, the processing of payments is decentralised. The national central banks (NCBs) transfer or deduct funds from their respective banking systems. It is for this reason that cross-border transactions involve the various central banks, giving rise to intra-system claims and liabilities, and thus the so-called "TARGET balances".

During the sovereign debt crisis there was a sharp increase in TARGET balances as a result of capital outflows from the countries affected. The sum of NCBs' liabilities/claims reached $€ 1.1$ trillion in August 2012 (see Chart 1.1). The subsequent easing of these tensions was reflected in a gradual reduction in TARGET balances. However, from 2015, coinciding with the start of a new stage of ECB monetary stimulus based on expansion of the Eurosystem's balance sheet, TARGET balances have increased again markedly. In October 2018, the aggregate positions stood at somewhat more than $€ 1.3$ trillion, with differences between countries in the sign and trend of such balances over the last four years (see Charts 1.3 and 1.4). In particular, Germany, Luxembourg, the Netherlands, Finland and Ireland are the main countries with claims, while the largest liabilities correspond to Italy, Spain, Portugal and the ECB itself. $^{3}$

This article analyses the increase in TARGET balances since 2015, focusing on the possible explanatory factors. Following this introduction, the second section analyses the origin of these balances, while the third discusses the main determinants of their increase and, lastly, the fourth section includes some final reflections.

TARGET2 is used to make payments in euro arising from commercial and financial transactions, including own account payments of banks with direct access to the system and payments made on behalf of their customers. In addition, all the ECB's monetary

1 TARGET2, which stands for Trans-European Automated Real-time Gross Settlement Express Transfer, is the second generation of TARGET and became fully operational in May 2008. The main characteristic of the previous TARGET system was also real-time gross settlement with central bank reserves, but it was a system of systems, set up by connecting the national real-time gross settlement (RTGS) systems of the European central banks. TARGET2 involved shifting to a single technical platform, shared by the member central banks, with harmonised services and prices.

2 See Alonso, J. and C. Conesa, (2013), "TARGET2: Qué significa y qué implica”, Papeles de la Fundación, No 49, Fundación de Estudios Financieros.

3 TARGET claims in October 2018 amounted to €928 billion in Germany (28\% of GDP), €224 billion in Luxembourg (398\% of GDP), $€ 92$ billion in the Netherlands (12\% of GDP), $€ 50$ billion in Finland ( $22 \%$ of GDP) and $€ 12$ billion in Ireland (4\% of GDP). The liability balances are: €490 billion for Italy ( $28 \%$ of GDP), €397 billion for Spain (34\% of GDP), €246 billion for the ECB, €79 billion for Portugal (40\% of GDP), €47 billion for Austria (12\% of GDP), $€ 29$ billion for Greece (16\% of GDP), €26 billion for France (1\% of GDP) and €5 billion for Belgium (1\% of GDP). By construction, the sum of all TARGET claims and liabilities (including EU countries not belonging to the euro area that have access to TARGET2 (Bulgaria, Croatia, Denmark, Poland and Romania)) is zero. 
Since 2015, TARGET balances have again increased substantially. This increase is associated with a situation of excess reserves, which unlike in the period 2011-2012, has been actively promoted by the ECB as part of its monetary stimulus policy. The asset purchase programme (APP) gives rise to the creation of TARGET balances when the acquisition transactions are cross border and the banks acting as counterparties or intermediaries are located in another euro area country. The most important positive positions are those of Germany, Luxembourg, the Netherlands and Finland, while Italy, Spain, Portugal and the ECB itself have the most important negative positions.

1 TARGET BALANCES. COUNTRY BREAKDOWN

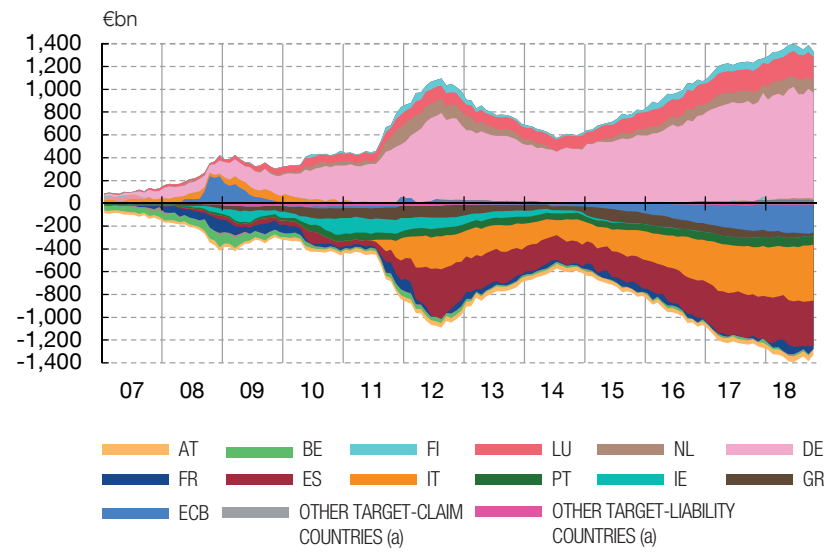

2 TARGET BALANCES AND ASSET PURCHASE PROGRAMME (APP)

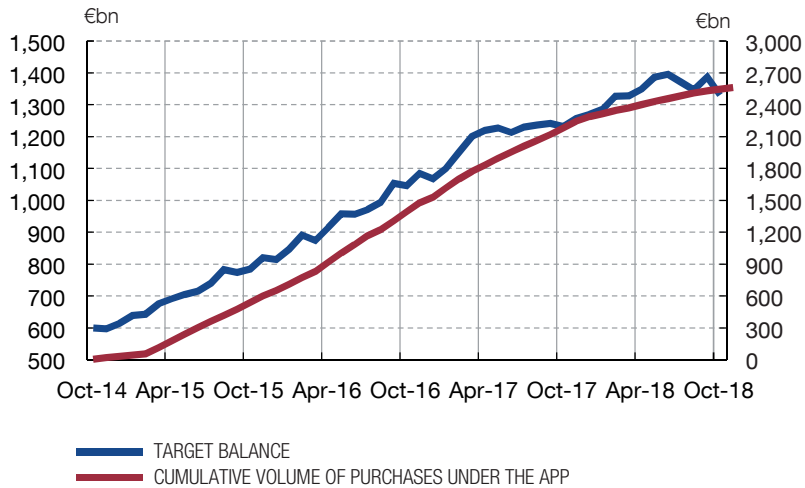

3 TARGET BALANCES IN CLAIM COUNTRIES

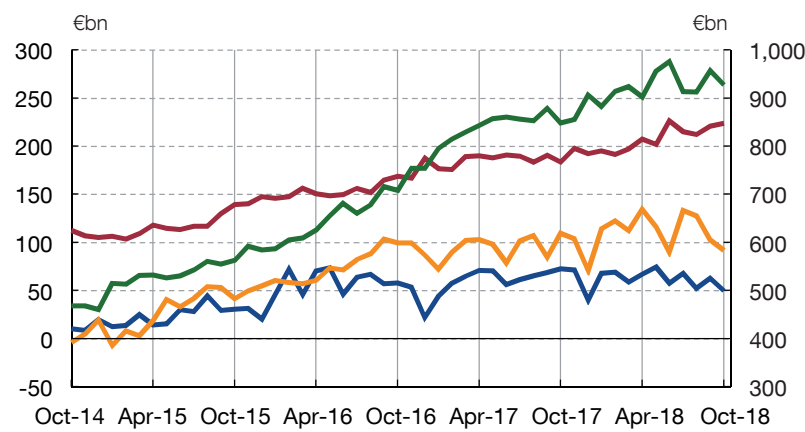

4 TARGET BALANCES IN LIABILITY COUNTRIES

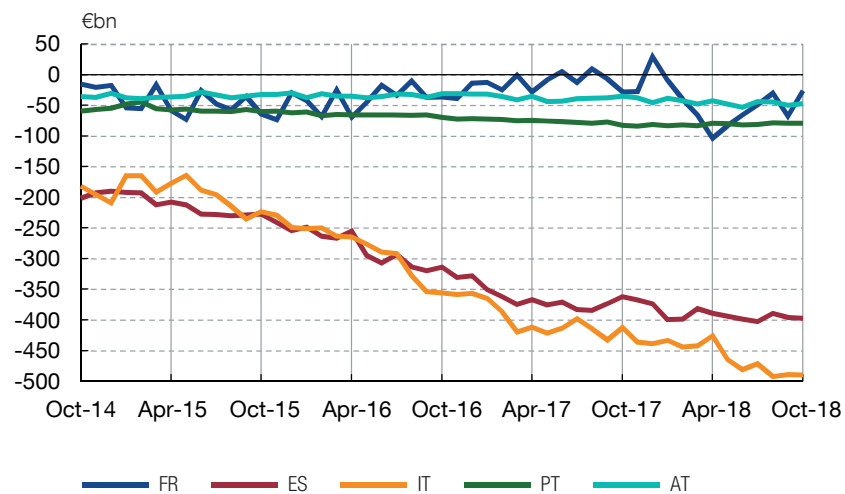

SOURCE: ECB.

a Includes all those countries that have joined the euro area since 2002 (by date of joining the monetary union: Slovenia, Malta, Cyprus, Slovakia, Estonia, Latvia and Lithuania), as well as those countries that do not belong to the euro area but have access to TARGET2 (Bulgaria, Croatia, Denmark, Poland and Rumania), which are aggregated according to whether they have a TARGET claim or liability.

Download

policy operations (excercised in a decentralised manner by the NCBs) are processed through TARGET2, including those providing liquidity to banks and securities purchases carried out at the initiative of the Eurosystem, for example under the asset purchase programme (APP).

The NCBs act as intermediaries between the banks paying and receiving funds, both in domestic and cross-border transactions, crediting or debiting reserves in the accounts participants hold at their respective central banks. Direct participation in TARGET2 is open to all credit institutions established in countries in the European Economic Area (EEA), ${ }^{4}$ as

4 The EEA is made up of the EU member states and three of the four countries in the European Free Trade Association (Iceland, Liechtenstein and Norway). 
The determinants of the increase in TARGET balances since 2015

well as to banks outside the EEA operating through a branch established in the EEA. Direct participation takes place through a settlement account at the central bank of the country in which the bank is resident. If the central bank in question does not participate in TARGET2 (e.g. the Bank of England), the bank may choose at which euro area central bank to open an account or participate indirectly through a correspondent account with a direct participant. Indirect participation, through correspondent accounts, is the channel for payments to agents in the rest of the world.

Transactions between domestic counterparties ${ }^{5}$ through TARGET2 do not affect the central bank's balance sheet, except insofar as reserves are transferred between the accounts of the banks involved held at the central bank. In cross-border transactions, however, as the credit and debit are made by different NCBs, an intra-system position arises between them. ${ }^{6}$ At the end of the day all the intra-system positions arising from cross-border transactions are aggregated and netted, to leave a single position for each NCB vis-à-vis the ECB, which is added to the balance (positive or negative) of previous transactions.

In general, the emergence of TARGET balances is the result of differences in cross-border receipts and payments between euro area countries through TARGET2: a net inflow (outflow) of funds into (out of) the country generates an increase (decrease) in the claim position or decrease (increase) in the liability position. TARGET balances are remunerated at the main refinancing rate, which has stood at $0 \%$ since March 2016 . However, these positions do not have any associated maturity period.

The factors behind the increase in TARGET balances since 2015 are very different from those that caused the increase during the sovereign debt crisis. In both cases they are associated with a situation of excess bank reserves, arising from the ECB's non-standard monetary policy measures since the start of the financial crisis and their concentration in particular countries. During the sovereign debt crisis, TARGET balances reflected severe tensions and malfunctioning in financial markets, leading to an increase in the demand for Eurosystem financing by the banks of certain countries, to meet their funding needs, given the difficulty of accessing the markets. However, the TARGET balances were not generated by Eurosystem financing (which does not entail cross-border flows of funds), but as a consequence of outflows of private funds. Nonetheless, the substantial growth in TARGET balances meant that they were interpreted as a measure of the intensity of the crisis in each economy. ${ }^{7}$

By contrast, the increase in TARGET balances since 2015 has not reflected a situation of financial stress or widespread funding problems in the euro area. Evidence for this is the coexistence in recent years of a large TARGET liability, in countries such as Spain, with portfolio investment by non-residents (particularly in government debt), and limited sovereign spreads (see Chart 2.2, which shows Spain's TARGET balance and the Spanish-German sovereign yield spread). That said, in the case of Italy, the change in the TARGET balance since May 2018 may have been affected by capital outflows stemming from the political instability and fiscal uncertainty in this country, which has also been reflected in a rise in its sovereign risk premium. ${ }^{8}$

5 Note that counterparties also include subsidiaries of foreign banks.

6 The central bank of the payer's bank reduces the reserves of such bank and records an intra-system liability. Thus it is necessary for the payer's bank to have funds in its account with the central bank, or else for the latter to extend the relevant credit, which must be duly collateralised. The central bank of the payee's bank increases the reserves of such bank and acquires an intra-system asset.

7 See ECB (2013), "Target balances and monetary policy operations", Monthly Bulletin, May; and A. Millaruelo and A. del Río (2013), "Las medidas de política monetaria no convencionales del BCE a lo largo de la crisis", Boletín económico, January, Banco de España.

8 See Banco de España (2018), "The political and fiscal uncertainty in Italy and the repercussions on financial markets”, Box 1.2, Financial Stability Report, November. 
Unlike during the sovereign debt crisis in 2011-2012, the growth in TARGET balances since 2015 in Spain does not reflect capital outflows arising from divestment by non-residents, but rather it has coexisted with a recovery in external surpluses, inflows of portfolio investment and capital outflows arising from residents' investment abroad. During this period, Spain's sovereign debt spread over Germany has remained relatively stable at reduced levels.

1 SPAIN. TARGET BALANCE AND BALANCE OF PAYMENTS Cumulated flows since January 2011

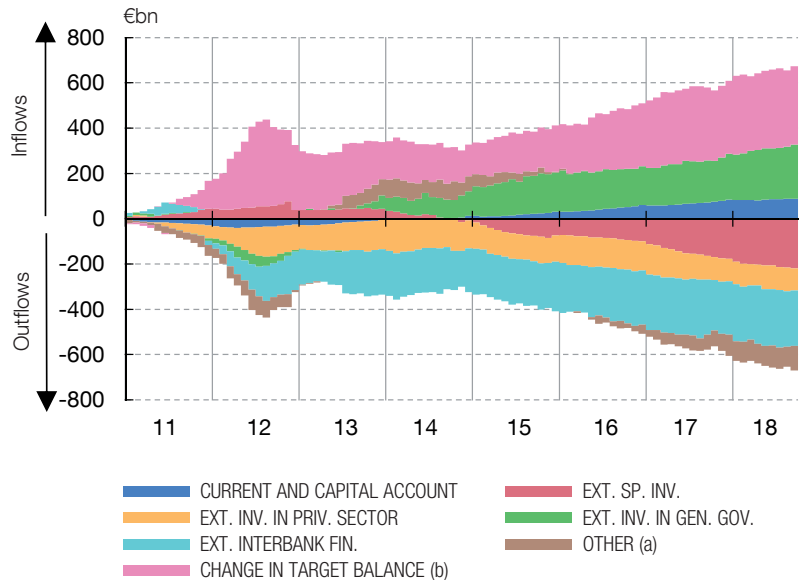

2 SPAIN. SOVEREIGN SPREAD AND TARGET BALANCE

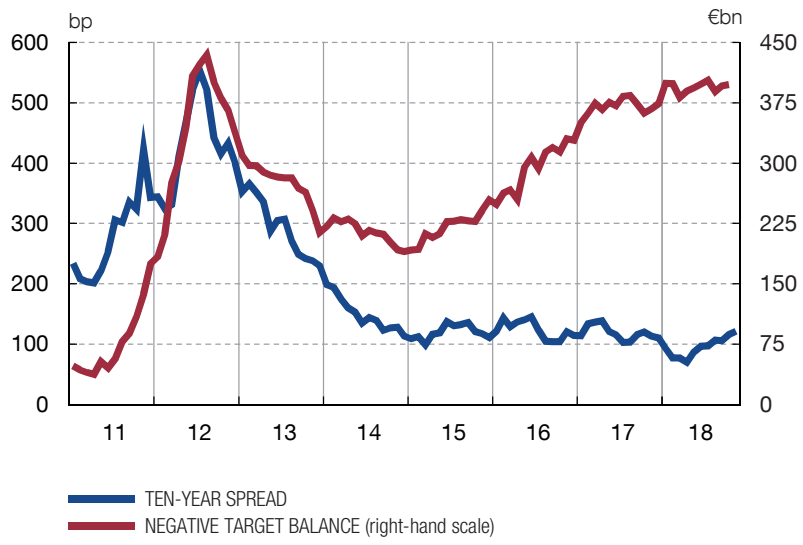

SOURCE: Banco de España, ECB and Datastream.

a Includes net direct investment, assets under the heading other investment, liabilities of other investment apart from the interbank market, the BE account excluding TARGET, net derivatives and errors and omissions.

b With the sign changed.

The increase in TARGET balances since 2015 is closely linked to the decentralised execution of the APP. The NCBs generate TARGET balances automatically when they buy assets from non-residents (located in another euro area country or the rest of the world) through counterparties located in other euro area countries. ${ }^{9}$ The automatic growth of TARGET balances with the decentralised execution of the APP is not determined by the seller's country of residence but the country of the central bank through which the counterparty performing or intermediating in the transaction operates in TARGET2 (see Figures 1 and 2 respectively). ${ }^{10}$

This is the case of UK banks, for example, which have traditionally connected to TARGET2 via the Bundesbank, either directly, or indirectly through German banks (see Figure 2). If, for example, the Banco de España buys bonds from a UK bank that has a correspondent account with a German commercial bank, when it receives the bonds the Banco de España incurs a matching liability with the Bundesbank, which increases the Banco de España's intrasystem liabilities and the Bundesbank's intrasystem claims. The latter, in turn, increases the reserves (central bank deposits) of the German commercial bank acting as the correspondent by the same amount. Lastly, the German bank credits the amount to the UK bank in its correspondent account.

9 See also Box 1 of the article, "The Eurosystem quantitative easing measures and the financial account", in the Economic Bulletin, April 2016, Banco de España.

10 The ECB's asset purchases under the APP have also generated intrasystem liabilities on the ECB's balance sheet, as credit institutions cannot hold accounts with the ECB, so the reserves are credited by the corresponding NCB. 
A Eurosystem national central bank (Country 1 NCB) buys bonds (green arrow) from a commercial bank resident in another euro area country (Country 2 (euro area) bank). The Country 2 NCB pays for the bonds by creating reserves (blue arrow). The payment by the Country 2 NCB on behalf of the Country 1 NCB is recognised as an asset item (TARGET claim) on the balance sheet of Country 2 NCB and a corresponding liability (TARGET liability) on the balance sheet of Country 1 NCB (red arrow).

The figure represents the stylised balance sheets of the commercial banks and the two NCBs involved in the transaction, showing only the items that have changed. The arrows between the balance sheets represent the financial flows associated with the transaction and the corresponding payment settlements; assets decrease (or liabilities increase) at the base of the arrow and assets increase (or liabilities decrease) at its head. The vertical arrows indicate the sign of the change (up for positive, down for negative).

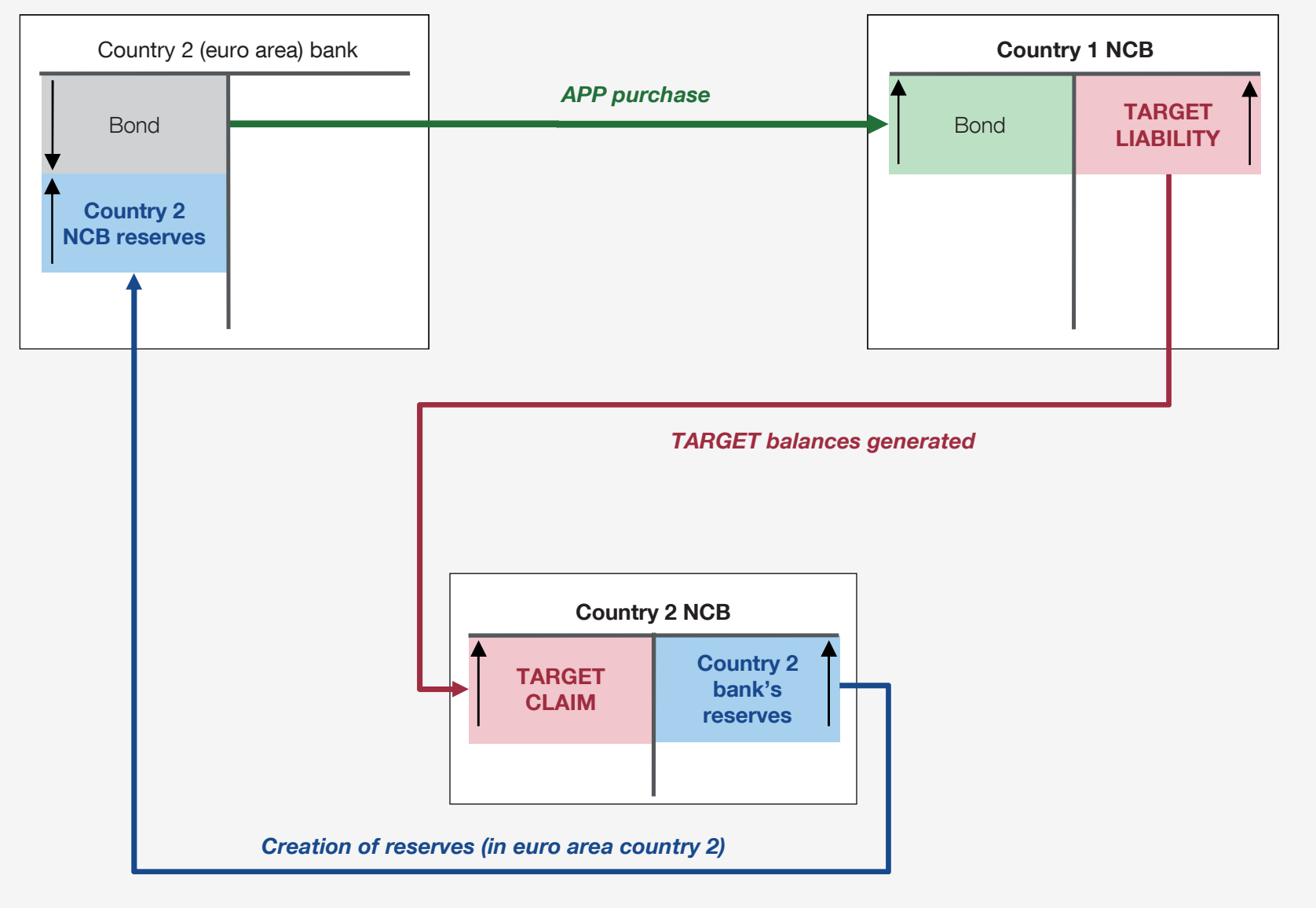

According to the ECB (2016), ${ }^{11}$ around $80 \%$ of securities purchasing by NCBs under the APP was carried out with non-domestic counterparties, and in approximately $50 \%$ of cases the ultimate seller was not resident in the euro area. Specifically, according to Praet, ${ }^{12}$ up until mid-2006 around $60 \%$ of the total volume of purchasing had been from counterparties participating in TARGET2 through the Bundesbank, whereas just $5 \%$ of purchasing had been through counterparties participating via the Banco de España. Therefore, the role of some financial centres in channelling flows of funds to euro area non-residents seems to explain a large part of the growth in net positive and negative positions in TARGET2. The

11 ECB (2016), "TARGET balances and the asset purchase programme", Economic Bulletin 7/2016.

12 Praet P. (2016), Remarks at the BNYM 20th anniversary dinner on the dynamics of TARGET2 balances and monetary policy implementation, speech on 15 September. 
A Eurosystem national central bank (Country 1 NCB) buys bonds (green arrow) from a commercial bank resident in a third (non-euro area) country (Non-resident (non-euro area) bank) and channels the payment through a correspondent commercial bank resident in another euro area country (Country 2 bank (correspondent)) that has access to the TARGET2 payment system. The Country 2 NCB pays the correspondent bank by creating reserves (blue arrow). The correspondent bank pays the bank selling the bonds with a credit in its correspondent account, which is recorded as a debit in the correspondent account of the selling bank (yellow arrow).

As in Figure 1, the payment by the Country 2 NCB on behalf of the Country 1 NCB is recognised on Country 2 NCB's balance sheet with an asset item (TARGET claim) and a liability item (TARGET liability) on the balance sheet of the Country 1 NCB (red arrow).

The figure represents the stylised balance sheets of the commercial banks and the two NCBs involved in the transaction, showing only the items that have changed. The arrows between the balance sheets represent the financial flows associated with the transaction and the corresponding payment settlements; assets decrease (or liabilities increase) at the base of the arrow and assets increase (or liabilities decrease) at its head. The vertical arrows indicate the sign of the change (up for positive, down for negative).

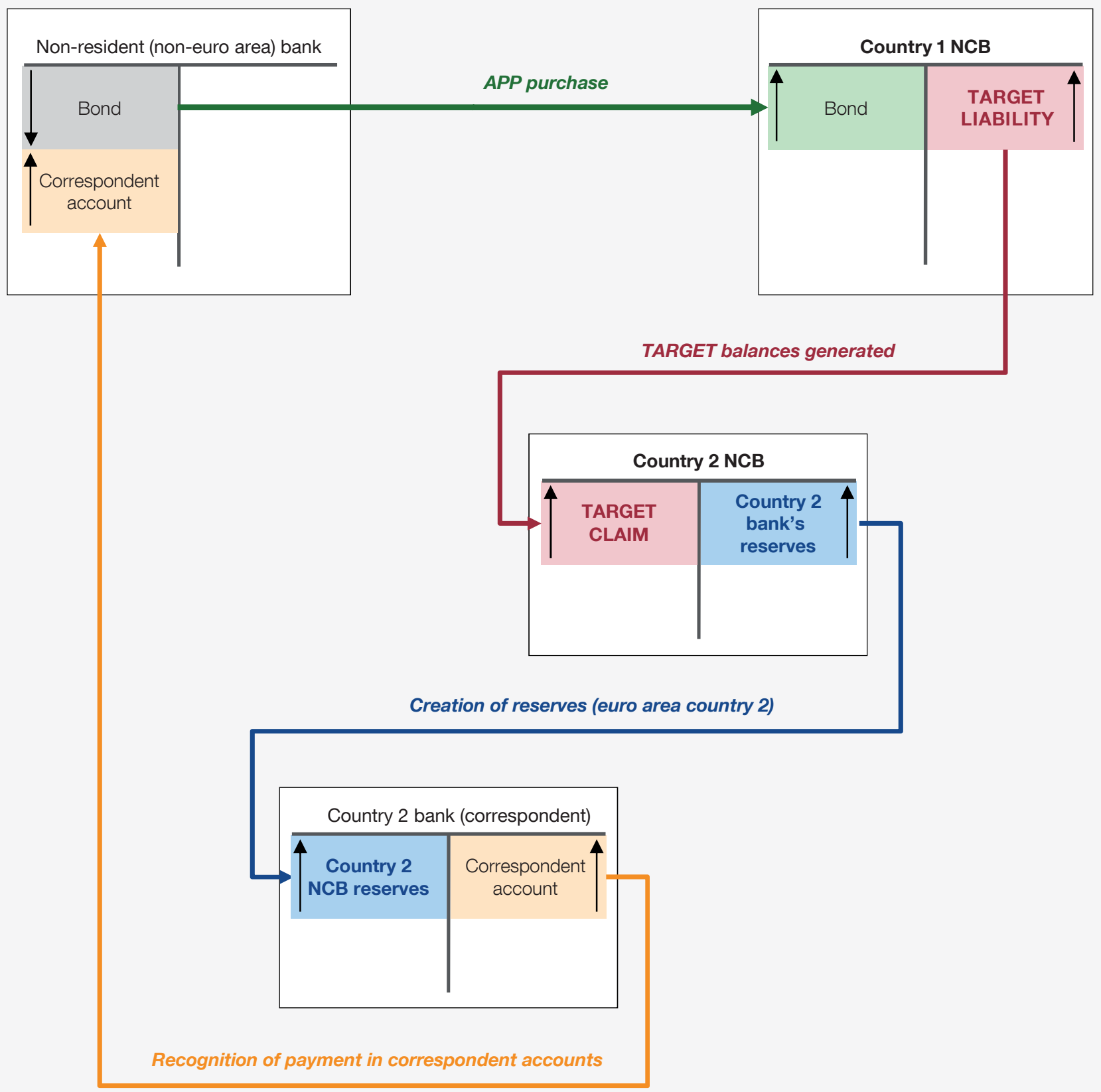


The NCBs generate TARGET balances automatically when they purchase assets from non-residents (located in another euro area country or the rest of the world) through counterparties located in other euro area countries. This automatic increase in TARGET balances with the decentralised execution of the APP is not determined by the seller's country of residence, but by the country of the central bank through which the counterparty carrying out or intermediating in the transaction operates in TARGET2.

1 EUROSYSTEM. TARGET BALANCES

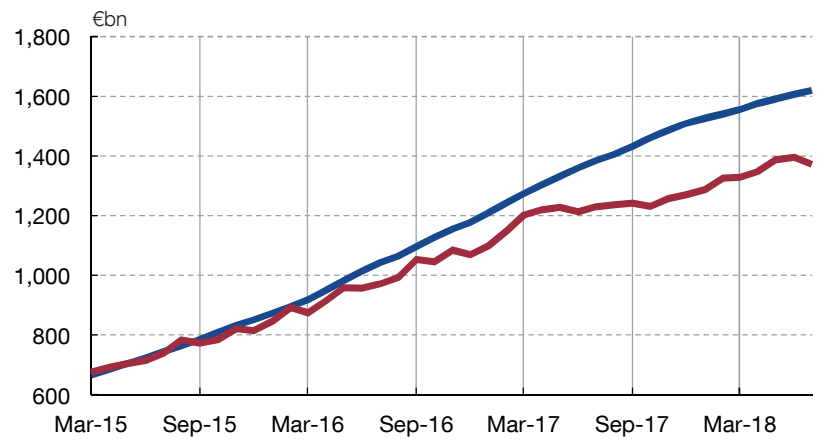

2 BANCO DE ESPAÑA TARGET BALANCES

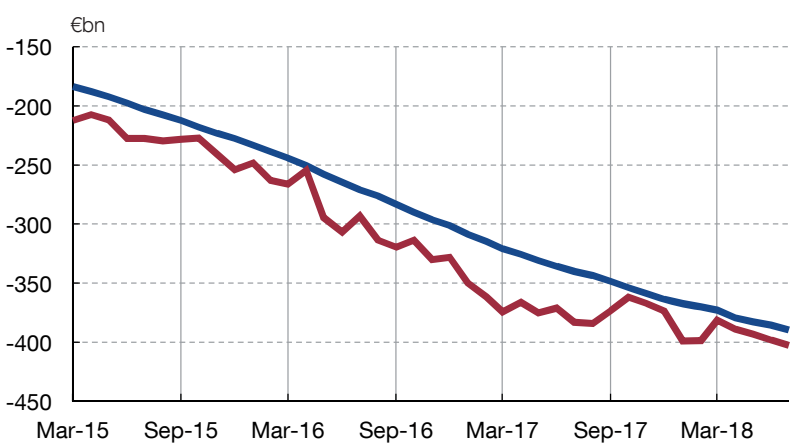

\section{SOURCE: Eurosystem.}

a The Eurosystem simulations illustrate how TARGET balances would have changed since March 2015 as a result of the cross-border payments arising from purchases of government bonds under the APP using data on transactions under the public sector purchase programme (PSPP) and the geographical location of the TARGET accounts of the transaction counterparties.

international banking business has traditionally been concentrated in Germany and the Netherlands, with Luxembourg being home to the investment funds industry, while Finland maintains close ties with Nordic banks outside the euro area.

According to the estimates shown in Chart $3,{ }^{13}$ which simulates the changes in TARGET balances deriving solely from cross-border payments resulting from government bond purchases by NCBs under the APP, these purchases would have led to an increase in TARGET balances of around $€ 1.6$ trillion in mid-2018. The fact that TARGET balances on that date did not exceed $€ 1.4$ trillion indicates that there has been a certain amount of redistribution within the euro area of the liquidity generated by the programme from countries with positive balances to countries with negative balances. In Spain's case, the value of the TARGET balance observed is very similar to that of the simulation, indicating that the net effect of all the other inflows and outflows of funds to and from Spain as a result of cross-border payments and collections through the TARGET2 system, which include flows associated with portfolio shifts by resident and non-resident agents, was practically zero.

Beyond the immediate impact of APP operations, TARGET balances may also be affected by the portfolio rebalancing process APP supports. The liquidity obtained from the sale of the asset may be held or alternatively transferred to another agent - domestic or foreign - by purchasing other assets or settling liabilities. The new agent receiving it will then be in

13 For more details see Eisenschmidt J., D. Kedan, M. Schmitz, R. Adalid and P. Papsdorf (2017), “The Eurosystem's asset purchase programme and TARGET balances”, Occasional Paper 196, September, European Central Bank. 
the same position as the initial seller, and may again hold this liquidity or pass it on to others. Cross-border payments within the euro area through TARGET2 deriving from this liquidity redistribution will affect the positions of central banks in TARGET2. In general, if the capital outflow from the euro area is largely channelled through banks located in specific countries, these flows will affect TARGET balances in the same way as execution of APP has (see Figure 3$).{ }^{14}$

In any event, the persistence of high TARGET balances in some countries indicates that circulation of liquidity associated with portfolio shifts has been insufficient to correct the concentration of reserves that the APP caused in some countries during its initial execution. The APP leads to excess bank reserves, ${ }^{15}$ with a distribution between countries that is, a priori, indeterminate. In this regard, if the relative sizes of the banking sectors are taken as a reference, reserves show relatively high levels in Germany, the Netherlands, Finland, and Luxembourg - countries with large positive TARGET balances (see Chart 4).

According to Baldo et al, ${ }^{16}$ one relevant factor in the distribution of reserves between NCBs is the predominant business model in each banking system. Thus, banks specialising in commercial credit, private banks, securities custody, deposit and settlement entities, and investment banks can usually hold greater excess reserves. By contrast, banks focusing on retail business or wholesale business with more stable deposit-based funding, tend to hold less excess liquidity. Universal banks lie somewhere in between. As well as the business model, there are other aspects of the area's financial structure that can affect the geographical distribution of reserves and TARGET balances, such as the level of centralisation of liquidity management by some international banking groups. Thus, some banking groups manage liquidity through the parent institution, from where they redistribute it to their subsidiaries, giving rise to cross-border movements.

However, Baldo et al. consider these factors to be insufficient to account for the relative stability of the distribution of banking reserves by country over time. One factor that seems relevant is the difference between countries in the opportunity cost of holding excess reserves in a context of differing yields on national debt, investors' risk aversion, and a domestic bias in banks' investment strategies. ${ }^{17}$ Under these conditions, reserves tend to accumulate in those banks for which holding them has a lower opportunity cost, both in terms of the return on alternative investment opportunities and cost of liabilities. One way

14 For example, if an Italian bank buys a US bond from a US bank with a correspondent account with a German bank, this transaction will increase the bond buyer's portfolio of securities issued by non-residents and diminish its reserve account at Banca d'Italia. In the central bank's liabilities, the reserves held by the Italian commercial bank will decrease, which will be offset by an increase in the bilateral TARGET liability vis-à-vis the Bundesbank and, at the end of the day, the net intrasystem TARGET liability vis-à-vis the ECB. On the asset side, at the Bundesbank this transaction will be recorded as an increase in the bilateral TARGET claims vis-à-vis Banca d'Italia, and, at the end of the day, in the net TARGET intrasystem claim vis-à-vis the ECB. On the liabilities side, the Bundesbank will increase the reserve account of the correspondent German bank. On the correspondent German bank's asset side there will be an increase in the reserve account at the Bundesbank, and the correspondent account held with the US bank will be credited. In the US bank, the bond portfolio will be reduced on the asset side and the amount of the sale will be debited from the correspondent account with the German commercial bank.

15 Note that the total volume of reserves cannot change unless a bank uses them to obtain cash, or buy assets, or repay loans to the central bank.

16 L. Baldo, B. Hallinger, C. Helmus, N. Herrala, D. Martins, F. Mohing, F. Petroulakis, M. Resinek, O. Vergote, B. Usciati and Y. Wang (2017), "The distribution of excess liquidity in the euro area", Occasional Paper No. 200, European Central Bank.

17 Various frictions cause differences in opportunity cost to arise: Baldo et al (2017) cite the internal risk control systems of some countries' commercial banks, which make potential investments with higher returns - such as the sovereign bonds issued by some euro area countries - unprofitable for banks in some countries in riskadjusted terms and in terms of regulatory cost. 
A commercial bank resident in Country 1 buys bonds (green arrow) from a commercial bank resident in a third, non-euro area, country (Nonresident (non-euro area) bank) with payment channelled through a correspondent commercial bank resident in another euro area country (Country 2 bank (correspondent)) with access to the TARGET2 payment system. To make the payment, the buyer reduces its reserves at the Country 1 NCB (blue arrow 1) and the Country 2 NCB pays the correspondent bank on behalf of the Country 1 NCB with an increase in reserves (blue arrow 2). The correspondent bank pays the seller with a credit to its correspondent account, which is recorded as a debit in the seller's correspondent account (yellow arrow).

The transfer of reserves between Country 1 and Country 2 NCBs is recognised on the Country 2 NCB's balance sheet with an asset item (TARGET claim) and the corresponding liability item (TARGET liability) on the Country 1 NCB's balance sheet (red arrow).

The figure represents the stylised balance sheets of the commercial banks and the two NCBs involved in the transaction, showing only the items that have changed. The arrows between the balance sheets represent the financial flows associated with the transaction and the corresponding payment settlements; assets decrease (or liabilities increase) at the base of the arrow and assets increase (or liabilities decrease) at its head. The vertical arrows indicate the sign of the change (up for positive, down for negative).

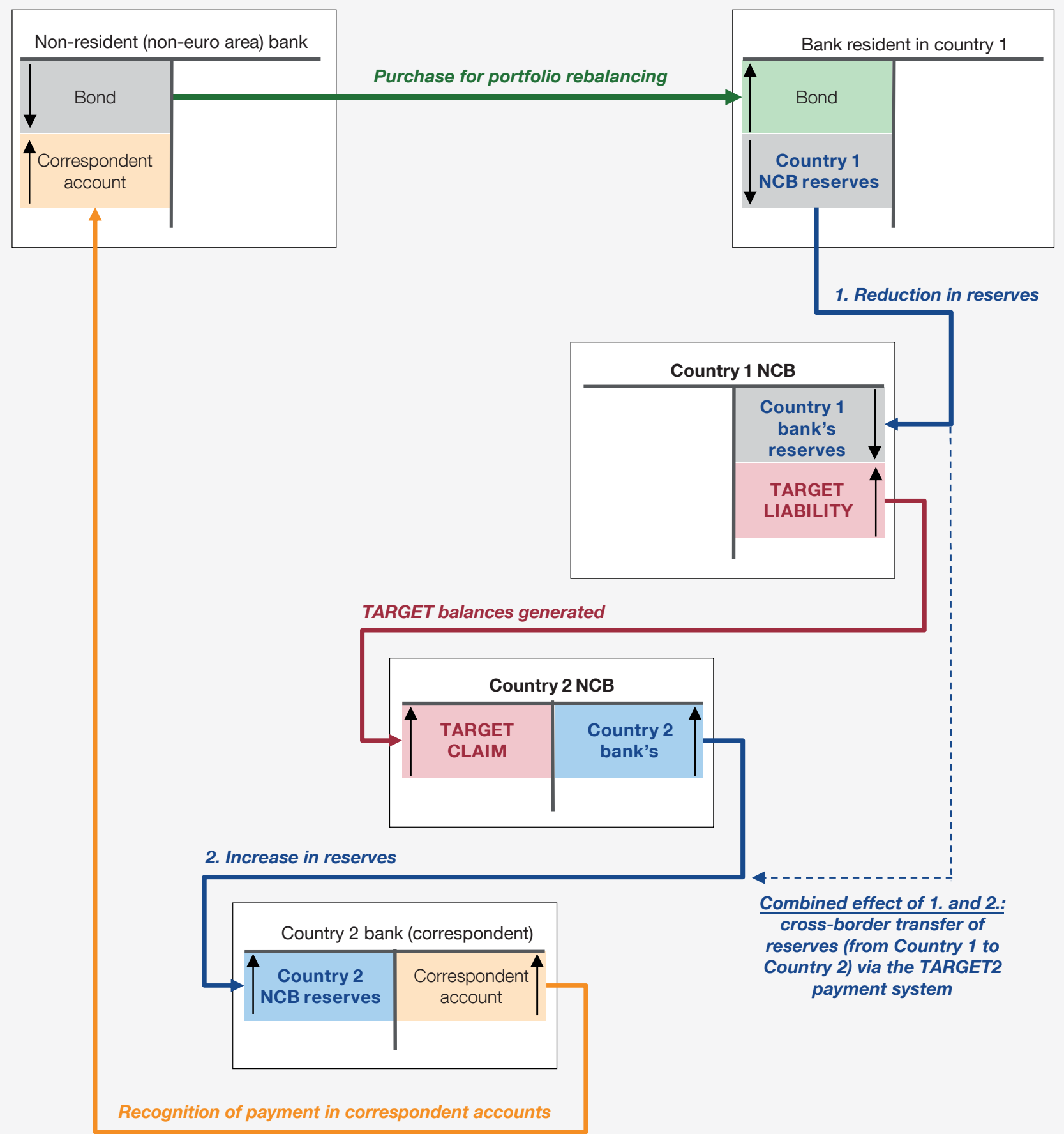


Asset purchases under the APP carried out by NCBs and the ECB are settled with the creation of bank reserves. The geographical location of the vendor of the asset or of the intermediary through which the transaction is channelled determines in which countries of the euro area the liquidity is created. Also, subsequent portfolio rebalancing or liquidity management decisions taken by banks may give rise to an additional geographical redistribution of the liquidity. A number of factors, such as the geographical location of counterparties or intermediaries, the geographical distribution of banks by business model, and risk-return considerations, determine the initial distribution and the subsequent redistribution of the liquidity created.

1 RESERVES IN THE EUROSYSTEM

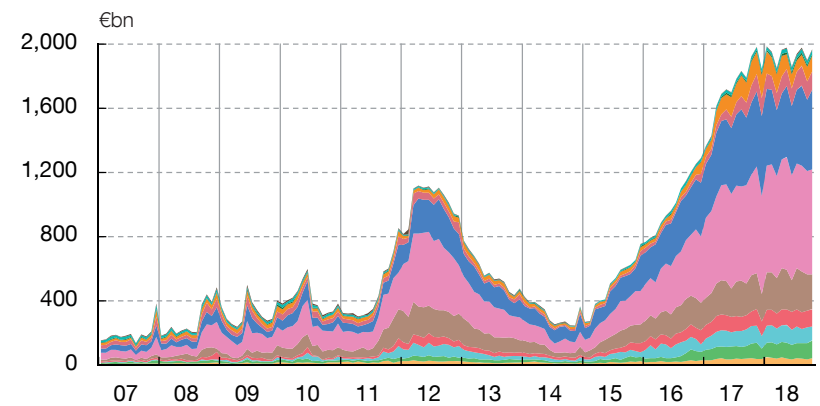

2 ASYMMETRIES IN THE DISTRIBUTION OF RESERVES (a) Deviation with respect to the relative size of the banking system

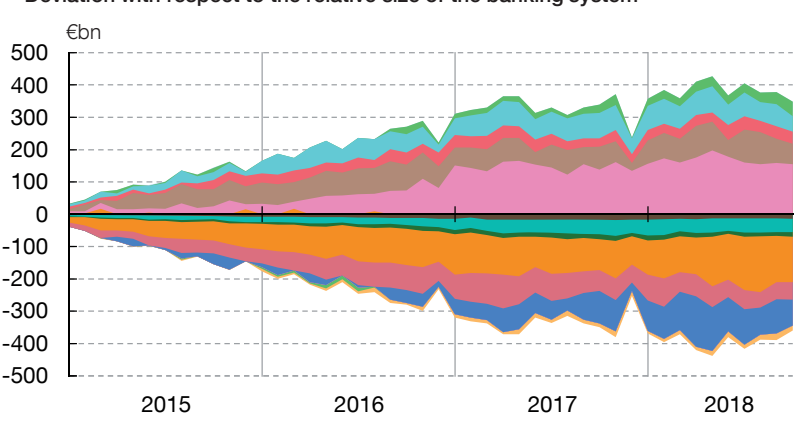

2015 2018
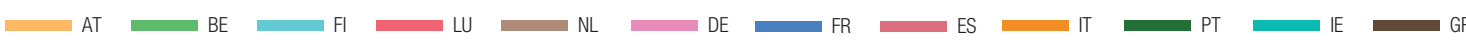

SOURCE: ECB.

a The asymmetry in the distribution of reserves is calculated in terms of the volume of total monthly reserves corresponding to each country according to the size of its banking system (measured as the total volume of assets banks have in that country in that month). Thus a country with a positive deviation is one that has a volume of reserves above the level it would have given the size of its banking system and vice versa.

Download

of proxying the relative attractiveness of reserves is to calculate the spread between the deposit facility interest rate $(-0.4 \%$ in the period $2016-2018)$ and the return on an alternative investment of similar risk and liquidity.

Considering two-year government debt as the alternative investment, a group of countries can be identified where reserves have grown most in relation to the size of the banking sector and for which this spread is positive. Most of the countries in this group are those with positive TARGET balances (countries shown in red in Chart 5.1, namely Germany, the Netherlands, Luxembourg and Finland). ${ }^{18}$ These countries' banks would even have to pay more to keep their excess liquidity in domestic two-year bonds than to leave it with the central bank. Additionally, a further group of countries with negative spreads can be identified (such as Italy, Spain and Portugal) that have accumulated a smaller volume of reserves, and have a growing negative TARGET balance. This suggests that the excess reserves held by banks in NCBs may be related to the opportunity cost of holding reserves.

Taking a very short-term (overnight) repo secured by the sovereign debt of the corresponding country (Chart 5.2) as the alternative investment, the relative return on the deposit facility is positive for all the countries shown, although a slightly positive relationship can be seen between the cumulative increase in reserves since the launch of the APP and its relative return. Again, this result confirms there to be something of a relationship between the reserves banks hold with NCBs and the opportunity cost of holding them.

18 This is largely due, as mentioned, to these countries being home to banks that act as correspondents for other banks outside the euro area. This implies that in these countries there has been abundant creation or inflow of reserves. 
The economies in which the bank reserves tend to be concentrated are those in which investing these surpluses in alternative assets with similar risk and liquidity, such as two-year sovereign debt or overnight repos, is less attractive. Accordingly, the banks of these countries prefer to hold surplus bank reserves, even though these are penalised with a negative return of $-0.40 \%$ (interest rate on the deposit facility), instead of other assets which have a still higher negative return.

1 SHORT-TERM PUBLIC DEBT (a)

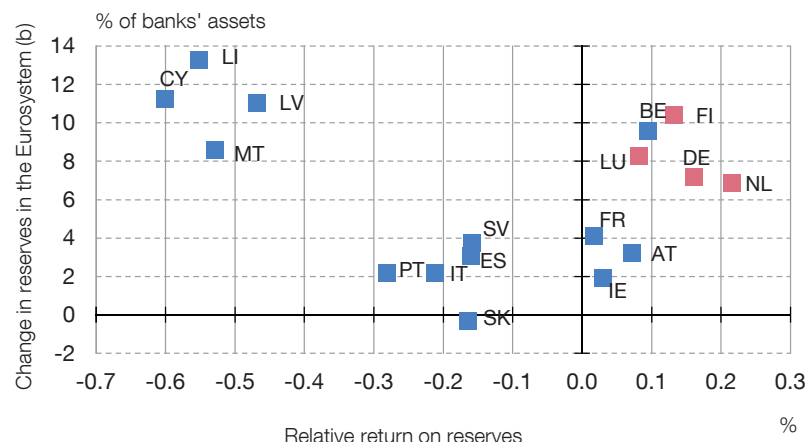

2 SOVEREIGN DEBT REPOS (c)

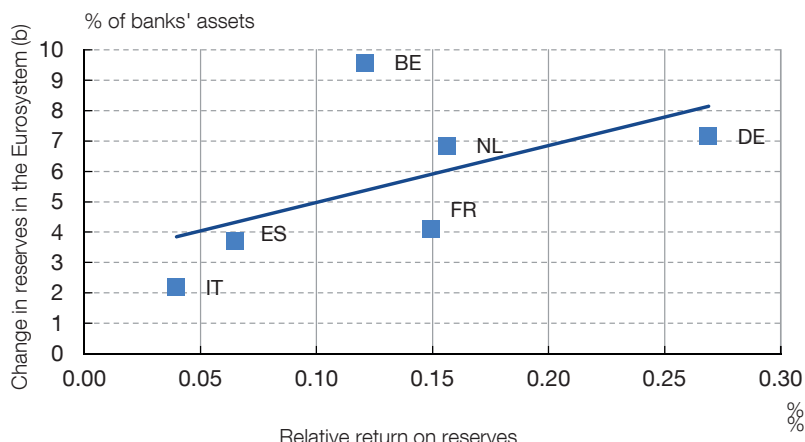

SOURCES: Banco de España, ECB and RepoFunds Rate.

a The relative return on reserves is calculated as the interest rate on the deposit facility less that on two or three-year national public debt (average for January-March 2018). Greece and Estonia are not included, owing to the unavailability of data. The countries indicated in red are those that have a higher positive TARGET balance and in which the accumulation of reserves has been greater in relation to the size of their banking system.

b This variable shows the change in bank reserves between January 2015 and October 2018 in each country in proportion to the size of the banking sytstem, measured as the total volume of bank assets in all the banks of such country.

c The relative return on the reserves is calculated as the interest rate on the deposit facility less that on overnight repos with the sovereign debt of the relevant country as collateral (average for January-March 2018).

Download

\section{Concluding remarks}

The increase in TARGET balances in the euro area since 2015 does not generally reflect situations of financial stress, or difficulties accessing external financing in countries with negative balances. The way these balances have developed is largely a consequence of the decentralised execution of the APP, in a context in which various factors have contributed to the tendency of reserves generated by this programme to be concentrated in certain countries. These factors include the persistence of differences between countries in the opportunity cost for banks of holding reserves in a context of differences in yields on national debt, investors' risk aversion, and a degree of domestic bias in banks' investment strategies.

Meanwhile, the concentration of banking reserves in certain countries should also not be interpreted as a sign that the APP has had a comparatively bigger impact in those economies. On the contrary, since the programme was launched, financing conditions in the countries that started out from a less favourable position, which are largely those that have seen the most moderate increases in their reserves relative to the size of their banking systems, have been those that have eased most, leading to a significant convergence in the conditions within the area as a result of greater - albeit incomplete-financial integration. 